\title{
5HT2A 受容体遺伝子多型が共感及び援助行動へ及ぼす影響
}

\author{
一近赤外分光法を用いた前頭前野腹外側部活動の検討一 \\ ○日道俊之 ${ }^{1,2} \cdot$ 野村理朗 $^{1}$ \\ ( ${ }^{1}$ 京都大学大学院教育学研究科 ${ }^{2}$ 日本学術振興会) \\ キーワード : $5 \mathrm{HT} 2 \mathrm{~A}$ 受容体遺伝子多型・前頭前野腹外側部・共感
}
5HT2A gene polymorphism influences empathy and helping behavior
Toshiyuki HIMICHI $^{1,2}$ and Michio NOMURA ${ }^{1}$
( ${ }^{1}$ Graduate School of Education, Kyoto Univ., ${ }^{2}$ JSPS)

Key Words: 5HT2A receptor gene polymorphism, Ventrolateral prefrontal cortex, Empathy

\section{目 的}

他者への共感は，他者理解を促すだけでなく援助行動を動 機づける(de Waal, 2012; Decety and Svetlova, 2012)。近年, こ のような共感を調整するプロセスが注目されており，前頭前 野外側部がこれに関与することが示されている(Lamm et al., 2010; Nomura et al, 2010)。我々の予備的研究においても，情動 反応の促進制御に関連する左前頭前野腹外側部(VLPFC:

ventrolateral prefrontal cortex)が，他者の悲しみへの共感反応を 調整し, 援助を動機づける可能性が示されている(Himichi and Nomura, under review)。しかし，このような共感の調整機構の 個人差に関する生物学的要因を検討した研究は少ない。

本研究では, 共感の調整機構の個人差に影響する生物学的 要因の 1 つとしてセロトニン $2 \mathrm{~A}(5 \mathrm{HT} 2 \mathrm{~A})$ 受容体遺伝子多型 (rs6311)に着目した。5HT2A 受容体遺伝子多型の AA 多型保有 者は GG 多型保有者に比べVLPFC が関与する反応制御が困難 であり (Nomura et al., 2006), VLPFC 機能が低い可能性がある (Nomura and Nomura, 2006)。よって, AA 多型保有者は G 多型 保有者 $(\mathrm{GG} \cdot \mathrm{AG}$ 多型保有者) と比心, 他者に共感する際の左 VLPFC 活動が低く, それに伴い他者援助も低い可能性が考え られる。本研究はそれを検証するため, 上記した予備的検討 のデータに参加者の遺伝子解析結果を加え, データの分析を 行った。

\section{方 法}

参加者 : 5HT2A 受容体遺伝子多型(rs6311)の解析結果より, 16 名が $\mathrm{G}$ 多型保有者(女性 12 名, 平均年齢: 20.81 歳, $S D=1.74$ ), $\mathrm{AA}$ 多型が 12 名(女性 : 6 名, 平均年齢 : 20.17 歳, $S D=0.80$ ) だった。多型頻度はハーディ・ワインベルグ平衡から脱して いなかった $\left(x^{2}(1)=0.73\right.$, n.s. $)$

手続き : 参加者は 2 名の架空の他者がカードゲームを行う場 面を, 一方の人物(ターゲット人物)の気持ちを想像しながら 観察した。カードゲームは互いに 1 枚ずつカードを選ぶのみ のゲームで, 勝つと 1 試行ごとに 50 円獲得でき, 負けると 50 円失うと教示した。各ゲームの後, 参加者はゲーム中の自 身の喜び・悲しみ感情やターゲット人物への共感の程度，援 助への動機づけを評定した後, ターゲット人物と 250 円を分 配した。ゲームの結果は予め操作されており, ターゲット人 物が負ける条件と, 引き分ける条件の 2 条件があった。参加 者はゲーム観察と主観評定, 金銭分配という手続きを, 条件 ごとに計 2 回行った。実験の最後に参加者にディブリーフィ ングを行い, 他のプレイヤーが完全に架空の人物だという確 信を持っていた参加者を分析から除外した。

fNIRS 測定: fNIRS(島津製作所，FOIRE-3000)で測定した，ゲ 一ム観察中(120 秒)の酸化へモグロビン濃度(oxy-Hb)の平均か らベースライン(ゲーム前 15 秒)の oxy-Hb の平均を減算した 值を活性值とした $(\Delta \mathrm{oxy}-\mathrm{Hb})$ 。なお, 先の実験(Himichi and Nomura, under review)の負け条件で不快感情や分配額と有意 な相関を示した左 VLPFC(ch41)のみ解析を行った。
結 果

左 VLPFC の $\triangle \mathrm{oxy}-\mathrm{Hb}$ について, ターゲット人物の結果(引 き分け/負け一参加者内要因 $) \times 5 \mathrm{HT} 2 \mathrm{~A}$ 受容体遺伝子多型 $(\mathrm{AA} / \mathrm{G}$ 一参加者間要因)の 2 要因混合分散分析を実施したとこ 万，交互作用が有意傾向だった $\left(F(1,26)=3.33, p=.080, \eta_{\mathrm{p}}{ }^{2}\right.$ $=.11)$ 。下位検定の結果, 負け条件における AA 多型の左 VLPFCの $\Delta \mathrm{oxy}-\mathrm{Hb}$ が, 負け条件における G 多型 $(F(1,26)=8.07$, $\left.p=.009, \eta_{\mathrm{p}}{ }^{2}=.24\right)$ 及び引き分け条件における AA多型のそれ に比べ $\left(F(1,26)=9.46, p=.005, \eta_{\mathrm{p}}{ }^{2}=.27\right)$ 有意に低かった。

また, 負け条件における左 VLPFC の $\triangle \mathrm{oxy}-\mathrm{Hb}$ と金銭分配 額が， $\mathrm{AA}$ 多型では有意な正の相関関係だったが $(r=.63, p$ $=.028), \mathrm{G}$ 多型では非有意だった $(r=.42, p=.109)$ さらに, 負け条件における左 VLPFC $の \triangle \mathrm{oxy}-\mathrm{Hb}$ と悲しみ評定が, AA 多型で有意傾向だが正の相関関係だったが $(r=.57, p=.055)$, $\mathrm{G}$ 多型では非有意だった $(r=.09, p=.732)$

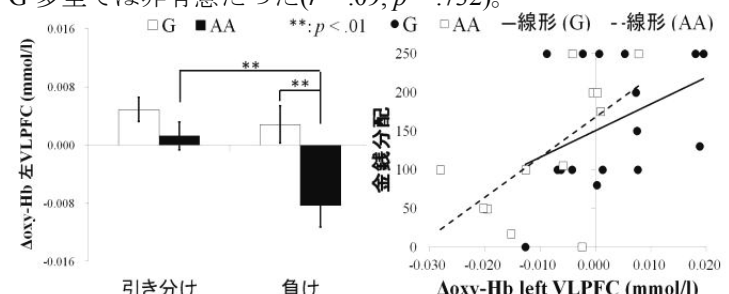

図. 各条件の左 VLPFC の $\Delta \mathrm{oxy}-\mathrm{Hb}$ の平均と標準誤差(左), 負け条件の左 VLPFC の $\Delta \mathrm{oxy}-\mathrm{Hb}$ と悲しみ評定(右)

\section{考 察}

5HT2A 受容体遺伝子多型 AA 多型保有者は $\mathrm{G}$ 多型保有者と 比べ, 他者の悲しみに共感している間の左 VLPFC 活性が低い ことが示された。また，AA 多型保有者のみ左 VLPFC 活性と 主観的な悲しみ評定の間に有意傾向だが正の相関関係が示さ れた。情動制御機能が共感を調節することが示唆されており (Decety and Svetlova, 2012), 左 VLPFC は情動反応の促進制御 に関与する(Ochsner et al., 2009)。よって本研究の結果は, AA 多型が VLPFC に基づく共感の調整機能が低い可能性を示し ていると考えられる。AA 多型保有者はVLPFC 機能が低い可 能性が示唆されており (Nomura and Nomura, 2006), 本研究の 結果はそれを支持するものであると考えられる。

また，AA 多型のみ分配額と左 VLPFC 活性の間に有意な正 の相関がみられた。共感は他者援助を動機づけることが示さ れていることから(Mathur et al., 2010), 共感を調節するVLPFC も同様に他者援助を促進すると考えられる。よって, 本研究 の結果は $\mathrm{AA}$ 多型の共感の調整機能の低さが, 後の援助行動 の低さを引き起こす可能性があることを示唆している。本研 究から, セロトニン神経系に関与寸る遺伝子多型が共感の調 整機能に関与し, それが後の援助行動に影響する可能性が示 された。
（日道俊之・野村理朗） 